\title{
Is Hong Kong Developing a Democratic Political Culture?
}

Jean-Philippe Béja

\section{(2) OpenEdition}

\section{Journals}

Édition électronique

URL : http://journals.openedition.org/chinaperspectives/1583

DOI : 10.4000/chinaperspectives. 1583

ISSN : 1996-4617

Éditeur

Centre d'étude français sur la Chine contemporaine

\section{Édition imprimée}

Date de publication : 15 avril 2007

ISSN : 2070-3449

Référence électronique

Jean-Philippe Béja, «Is Hong Kong Developing a Democratic Political Culture? », China Perspectives [En ligne], 2007/2 | 2007, mis en ligne le 08 avril 2008, consulté le 28 octobre 2019. URL : http://

journals.openedition.org/chinaperspectives/1583; DOI : 10.4000/chinaperspectives.1583 


\title{
Is Hong Kong Developing a
}

\section{Democratic Political Culture?}

\author{
IEAN-PHILIPPE BÉJA
}

$66 T$ ong Kong will not be ready for universal suffrage until around 2022 because its people lack a sense of national identity ${ }^{(1)}$. This declaration by Ma Lik, chairman of the pro-Beijing Democratic Alliance for the Betterment and Progress of Hong Kong, shows how the question of national identity is so central to political debate in Hong Kong that it sets the terms for the territory's democratic development, even though this is already laid down in the Basic Law.

Since 1997 the authorities have frequently denounced what they see as "foreign" in the political culture of the former colony. For example, in 2002 the Chief Executive Tung Chee-hwa stated his desire to change it, when he attacked Martin Lee for criticising his leadership ${ }^{(2)}$ : "Our culture is changing. It is in nobody's interest to continually badmouth Hong Kong ${ }^{(3) . " ~ I n ~ t h e ~ s a m e ~ v e i n, ~ t h e ~ B e i j i n g ~ l e a d e r s h i p ~ h a s ~}$ constantly reiterated over the last ten years that the Hong Kong population ought to display more patriotism (which in Chinese communist-speak means supporting the Party). That is why, in their eagerness to please the central government, the SAR authorities decided to have the national anthem played regularly on the television.

National identity is unquestionably an important element in a political culture, but, when analysing this concept in its context, it is useful to explore how the people of Hong Kong themselves see their identity. Regular surveys have been conducted to throw light on the SAR's inhabitants' attitudes, and they reveal a contrasted image. Experts in this area have agreed on a definition of four different kinds of identity: two place the emphasis on membership of the SAR, namely "Hong Kong citizens" (Heunggong yahn 香港人) and "Hong Kong citizens of Chinese origin" (Junggwok dik Heunggong yahn 中國的香港人), while the other two emphasise Chinese identity, namely "Chinese" (Junggwok yahn 中國人) and "Chinese citizens of Hong Kong" ( $\mathrm{He}$ unggong dik Junggwok yahn 香港的中國人).

The survey results show that since 1997 over half the people interviewed have opted for one of the first two categories, which means they attach great importance to the special status of Hong Kong. And even though there is a noticeable regular increase in the percentage of inhabitants who stress their belonging to China, they are still in a minority. This justifies the approach of this article, which will be to study those elements which are specific to Hong Kong's political culture.

\section{The emergence of a specific Hong Kong political culture}

Starting in the 1970s, the former British colony saw the development of its own political culture, focused on the defence of basic human rights. This underwent continual development throughout the 1980s, and the Beijing authorities certainly made their own contribution by setting up the Basic Law Drafting Committee and the Basic Law Consultative Committee, to which, for the first time, representatives from the various active sectors of the colony's population were invited to express their opinion on the Territory's future. These institutions functioned as a kind of school in political participation, just like the Legislative Council (Legco) which had recently admitted elected members. It can be said therefore that the actions of the Beijing government helped to increase local people's interest in politics, particularly among the middle classes whose importance was steadily increasing.

But there can be no doubt that it was the pro- democracy movement in China which was a watershed in the formation of the political culture of Hong Kong. When the students began to demonstrate in the streets of Beijing in April 1989, there was immediate sympathy on the part of the Hong Kong population, especially among the youth. And on 20 May, when Chinese Prime Minister Li Peng declared martial law, the entire population was galvanised. The PRC regime, which eight years later was to rule Hong Kong, revealed its brutality. "Beijing's today is Hong Kong's tomorrow" was one of the slogans repeated by the million demonstrators (out of a population of five million) who took to the

\footnotetext{
1. Ambrose Leung, "Furore at DAB's Chief Tirade," South China Morning Post, 15 May 2007

2. Lee had accused Tung of turning the SAR into a "sick chicken" (in place of the former goose that laid the golden eggs).

3. South China Morning Post, 8 February 2002.
} 
Table 1. The question of identity

\begin{tabular}{|c|c|c|c|c|c|c|c|}
\hline Date of survey & $\begin{array}{c}\text { Total } \\
\text { Sample }\end{array}$ & $\begin{array}{c}\text { Sub- } \\
\text { sample }\end{array}$ & $\begin{array}{l}\text { Hong Kong } \\
\text { Citizen + } \\
\text { Chinese Hong } \\
\text { Kong Citizen }\end{array}$ & $\begin{array}{c}\text { Chinese } \\
\text { Citizen + } \\
\text { Hong Kong } \\
\text { Chinese } \\
\text { Citizen } \\
\end{array}$ & Other & DK/HS & Total \\
\hline $6-12 / 12 / 2006$ & 1011 & 1011 & $54.3 \%$ & $44.4 \%$ & $0.6 \%$ & $0.7 \%$ & $100.0 \%$ \\
\hline $13-15 / 6 / 2006$ & 1018 & 1018 & $59.4 \%$ & $40.0 \%$ & $0.3 \%$ & $0.3 \%$ & $100.0 \%$ \\
\hline $9-14 / 12 / 2005$ & 1017 & 1017 & $51.3 \%$ & $47.6 \%$ & $0.0 \%$ & $1.1 \%$ & $100.0 \%$ \\
\hline $6-8 / 6 / 2005$ & 1029 & 1029 & $45.2 \%$ & $51.1 \%$ & $0.5 \%$ & $3.3 \%$ & $100.0 \%$ \\
\hline $6-9 / 12 / 2004$ & 1007 & 1007 & $49.0 \%$ & $47.8 \%$ & $0.4 \%$ & $2.8 \%$ & $100.0 \%$ \\
\hline $7-11 / 6 / 2004$ & 1027 & 1027 & $49.2 \%$ & $47.3 \%$ & $0.4 \%$ & $3.1 \%$ & $100.0 \%$ \\
\hline $10-14 / 12 / 2003$ & 1059 & 1059 & $48.3 \%$ & $48.1 \%$ & $0.3 \%$ & $3.3 \%$ & $100.0 \%$ \\
\hline $13-18 / 6 / 2003$ & 1043 & 1043 & $55.9 \%$ & $40.9 \%$ & $0.7 \%$ & $2.5 \%$ & $100.0 \%$ \\
\hline $1-4 / 3 / 2003$ & 1035 & 1035 & $50.8 \%$ & $47.3 \%$ & $0.3 \%$ & $1.6 \%$ & $100.0 \%$ \\
\hline $13-18 / 12 / 2002$ & 1026 & 1026 & $52.4 \%$ & $44.0 \%$ & $0.6 \%$ & $3.0 \%$ & $100.0 \%$ \\
\hline $2-5 / 9 / 2002$ & 1017 & 1017 & $50.9 \%$ & $47.5 \%$ & $0.4 \%$ & $1.2 \%$ & $100.0 \%$ \\
\hline $4-5 / 6 / 2002$ & 1067 & 1067 & $50.3 \%$ & $45.5 \%$ & $0.4 \%$ & $3.9 \%$ & $100.0 \%$ \\
\hline $12-13 / 3 / 2002$ & 1024 & 1024 & $50.8 \%$ & $46.2 \%$ & $0.0 \%$ & $3.0 \%$ & $100.0 \%$ \\
\hline $7-9 / 12 / 2001$ & 1052 & 1052 & $52.4 \%$ & $41.9 \%$ & $0.3 \%$ & $5.4 \%$ & $100.0 \%$ \\
\hline $13-21 / 9 / 2001$ & 1025 & 1025 & $54.0 \%$ & $43.4 \%$ & $0.4 \%$ & $2.1 \%$ & $100.0 \%$ \\
\hline $1-5 / 6 / 2001$ & 1053 & 1053 & $54.4 \%$ & $41.7 \%$ & $0.0 \%$ & $3.8 \%$ & $100.0 \%$ \\
\hline $22 / 3-2 / 4 / 2001$ & 1014 & 1014 & $53.1 \%$ & $44.2 \%$ & $0.4 \%$ & $2.3 \%$ & $100.0 \%$ \\
\hline $4-12 / 12 / 2000$ & 1040 & 1040 & $54.7 \%$ & $39.0 \%$ & $0.9 \%$ & $5.5 \%$ & $100.0 \%$ \\
\hline $21-25 / 9 / 2000$ & 1087 & 1087 & $63.8 \%$ & $31.9 \%$ & $0.4 \%$ & $3.9 \%$ & $100.0 \%$ \\
\hline $7-8 / 6 / 2000$ & 1074 & 1074 & $58.4 \%$ & $36.8 \%$ & $0.7 \%$ & $4.1 \%$ & $100.0 \%$ \\
\hline $6-7 / 4 / 2000$ & 570 & 570 & $60.1 \%$ & $34.6 \%$ & $0.2 \%$ & $5.1 \%$ & $100.0 \%$ \\
\hline $1-2 / 2 / 2000$ & 566 & 566 & $61.5 \%$ & $33.3 \%$ & $0.5 \%$ & $4.6 \%$ & $100.0 \%$ \\
\hline 13-15/12/1999 & 529 & 529 & $59.9 \%$ & $37.1 \%$ & $0.2 \%$ & $2.8 \%$ & $100.0 \%$ \\
\hline $26-27 / 10 / 1999$ & 535 & 535 & $54.9 \%$ & $41.7 \%$ & $0.7 \%$ & $2.6 \%$ & $100.0 \%$ \\
\hline 6/8/1999 & 596 & 596 & $53.6 \%$ & $42.8 \%$ & $0.3 \%$ & $3.2 \%$ & $100.0 \%$ \\
\hline 8/6/1999 & 538 & 538 & $64.9 \%$ & $28.2 \%$ & $0.6 \%$ & $6.3 \%$ & $100.0 \%$ \\
\hline $15 / 4 / 1999$ & 527 & 527 & $63.4 \%$ & $31.1 \%$ & $0.4 \%$ & $5.1 \%$ & $100.0 \%$ \\
\hline $8-9 / 2 / 1999$ & 513 & 513 & $61.9 \%$ & $32.9 \%$ & $1.2 \%$ & $3.9 \%$ & $100.0 \%$ \\
\hline 21/12/1998 & 544 & 544 & $63.0 \%$ & $32.3 \%$ & $0.6 \%$ & $4.2 \%$ & $100.0 \%$ \\
\hline 29/9/1998 & 517 & 517 & $62.3 \%$ & $36.1 \%$ & $0.4 \%$ & $1.2 \%$ & $100.0 \%$ \\
\hline $14 / 8 / 1998$ & 526 & 526 & $54.9 \%$ & $41.6 \%$ & $0.2 \%$ & $3.2 \%$ & $100.0 \%$ \\
\hline $22-24 / 6 / 1998$ & 1042 & 1042 & $48.2 \%$ & $47.7 \%$ & $0.4 \%$ & $3.8 \%$ & $100.0 \%$ \\
\hline $3-4 / 6 / 1998$ & 544 & 544 & $52.8 \%$ & $43.5 \%$ & $0.2 \%$ & $3.4 \%$ & $100.0 \%$ \\
\hline $8-9 / 12 / 1997$ & 500 & 500 & $58.7 \%$ & $37.1 \%$ & $0.2 \%$ & $3.9 \%$ & $100.0 \%$ \\
\hline 28-29/10/1997 & 536 & 536 & $59.2 \%$ & $37.6 \%$ & $0.2 \%$ & $3.0 \%$ & $100.0 \%$ \\
\hline 23-24/9/1997 & 512 & 512 & $60.4 \%$ & $37.8 \%$ & $0.2 \%$ & $1.6 \%$ & $100.0 \%$ \\
\hline $26-27 / 8 / 1997$ & 532 & 532 & $59.7 \%$ & $38.7 \%$ & $0.4 \%$ & $1.3 \%$ & $100.0 \%$ \\
\hline
\end{tabular}



Table 2. "Do you think that the Chinese Government did the right thing in the June 4 Incident?"

\begin{tabular}{|c|c|c|c|c|}
\hline $\begin{array}{l}\text { Date of } \\
\text { Survey }\end{array}$ & Right & Wrong & $\begin{array}{c}\text { Don't } \\
\text { know / } \\
\text { Hard to } \\
\text { say }\end{array}$ & Total \\
\hline $18-25 / 5 / 06$ & $17.8 \%$ & $63.4 \%$ & $18.8 \%$ & $100.0 \%$ \\
\hline $21-24 / 5 / 05$ & $12.6 \%$ & $62.4 \%$ & $25.0 \%$ & $100.0 \%$ \\
\hline $18-20 / 5 / 04$ & $9.5 \%$ & $66.6 \%$ & $24.0 \%$ & $100.0 \%$ \\
\hline $15-20 / 5 / 03$ & $12.5 \%$ & $61.6 \%$ & $25.9 \%$ & $100.0 \%$ \\
\hline $14-16 / 5 / 02$ & $13.6 \%$ & $53.2 \%$ & $33.2 \%$ & $100.0 \%$ \\
\hline $25-29 / 5 / 01$ & $14.1 \%$ & $56.4 \%$ & $29.4 \%$ & $100.0 \%$ \\
\hline $30-31 / 5 / 00$ & $10.5 \%$ & $60.8 \%$ & $28.7 \%$ & $100.0 \%$ \\
\hline $24 / 5 / 99$ & $12.2 \%$ & $56.8 \%$ & $31.0 \%$ & $100.0 \%$ \\
\hline $26 / 5 / 98$ & $13.3 \%$ & $55.2 \%$ & $31.5 \%$ & $100.0 \%$ \\
\hline $27 / 5 / 97$ & $10.0 \%$ & $63.1 \%$ & $26.8 \%$ & $100.0 \%$ \\
\hline $22-23 / 5 / 96$ & $6.5 \%$ & $72.1 \%$ & $21.4 \%$ & $100.0 \%$ \\
\hline $29-31 / 5 / 95$ & $9.0 \%$ & $71.9 \%$ & $19.0 \%$ & $100.0 \%$ \\
\hline $17-20 / 5 / 94$ & $7.2 \%$ & $76.7 \%$ & $16.1 \%$ & $100.0 \%$ \\
\hline $10-11 / 5 / 93$ & $5.7 \%$ & $77.1 \%$ & $17.2 \%$ & $100.0 \%$ \\
\hline
\end{tabular}

Zilin, founder of the Tiananmen mothers' organisation. They shout slogans calling for the rehabilitation of the movement, sing the songs which accompanied the 1989 demonstrations, and reaffirm their commitment to democracy in Hong Kong. It is a sort of secular democratic ritual. Despite the passing of the years, the return of Hong Kong to the motherland, and the replacement of one Chief Executive by another, the vigil on 4 June still attracts considerable crowds. This vigil constitutes an essential part of the political culture, and even of the political identity of Hong Kong. By commemorating those who gave their lives for democracy in Beijing, they declare their own commitment to that cause. At the same time, they express their conviction that only the introduction of democracy will enable the SAR's identity to be maintained.

However, the authorities are doing everything in their power to persuade the Hongkongers to give up this tradition. Ten years ago, Tung Chee-hwa, the Chief Executive appointed by the mainland authorities, declared just before taking up office that the population would do well to "abandon the
Table 3. "Do you support a revision of the official stand on the 4 June incident?"

\begin{tabular}{|c|c|c|c|c|}
\hline $\begin{array}{l}\text { Date of } \\
\text { Survey }\end{array}$ & Yes & No & $\begin{array}{c}\text { Don't } \\
\text { know / } \\
\text { Hard to } \\
\text { say }\end{array}$ & Total \\
\hline $18-25 / 5 / 06$ & $56.2 \%$ & $28.1 \%$ & $15.8 \%$ & $100.0 \%$ \\
\hline $21-24 / 5 / 05$ & $56.1 \%$ & $21.0 \%$ & $22.8 \%$ & $100.0 \%$ \\
\hline $18-20 / 5 / 04$ & $54.1 \%$ & $22.6 \%$ & $23.3 \%$ & $100.0 \%$ \\
\hline $15-20 / 5 / 03$ & $46.6 \%$ & $24.1 \%$ & $29.3 \%$ & $100.0 \%$ \\
\hline $14-16 / 5 / 02$ & $39.1 \%$ & $26.6 \%$ & $34.3 \%$ & $100.0 \%$ \\
\hline $25-29 / 5 / 01$ & $40.3 \%$ & $26.3 \%$ & $33.4 \%$ & $100.0 \%$ \\
\hline $30-31 / 5 / 00$ & $47.1 \%$ & $22.2 \%$ & $30.7 \%$ & $100.0 \%$ \\
\hline $24 / 5 / 99$ & $45.6 \%$ & $21.6 \%$ & $32.8 \%$ & $100.0 \%$ \\
\hline $26 / 5 / 98$ & $48.5 \%$ & $19.0 \%$ & $32.5 \%$ & $100.0 \%$ \\
\hline $27 / 5 / 97$ & $49.9 \%$ & $18.9 \%$ & $31.2 \%$ & $100.0 \%$ \\
\hline
\end{tabular}

June 4th baggage" and look to the future. Rumours about public works in Victoria Park raised fears that the celebrations to mark the ninth anniversary of the massacre could not take place. Despite such fears, 50,000 people gathered together on the eve of the first anniversary since the handover, and for the fifteenth anniversary in 2004, there were 82,000 participants ${ }^{(5)}$. This was the largest gathering since 1997.

This regular event has an undeniable importance in the political life of Hong Kong. All the opinion polls show that the population continues to condemn the massacre carried out by the People's Liberation Army eighteen years ago. To the question "Do you think the Chinese Government did the right thing in the June 4 Incident?" the number of negative replies was $63.1 \%$ in 1997 , and $63.4 \%$ in 2006 . These figures reveal a remarkable consistency.

The natural sequel to this condemnation is that the majority of those questioned believe that the Chinese Government ought to revise its stand on the movement in Tiananmen Square. We even find that the proportion of those in favour of this proposal has increased since 1997, despite the pressures in the dominant discourse to play down the importance of those events.

5. Keith Bradsher, "Hong Kong Crowds Mark Tiananmen Square Killings," International Herald Tribune, 5 June 2004, and Klaudia Lee, "No longer just a vigil but a fight," South China Morning Post, 5 June 2004. 
Table 4. "Do you think the Alliance should be disbanded?"

\begin{tabular}{|c|c|c|c|c|}
\hline $\begin{array}{l}\text { Date of } \\
\text { Survey }\end{array}$ & Yes & No & $\begin{array}{c}\text { Don't } \\
\text { know / } \\
\text { Hard to } \\
\text { say }\end{array}$ & Total \\
\hline $18-25 / 5 / 06$ & $21.2 \%$ & $51.3 \%$ & $27.5 \%$ & $100.0 \%$ \\
\hline $21-24 / 5 / 05$ & $18.6 \%$ & $46.7 \%$ & $34.7 \%$ & $100.0 \%$ \\
\hline $18-20 / 5 / 04$ & $15.5 \%$ & $52.4 \%$ & $32.1 \%$ & $100.0 \%$ \\
\hline $15-20 / 5 / 03$ & $17.2 \%$ & $43.0 \%$ & $39.8 \%$ & $100.0 \%$ \\
\hline $14-16 / 5 / 02$ & $17.7 \%$ & $39.6 \%$ & $42.6 \%$ & $100.0 \%$ \\
\hline $25-29 / 5 / 01$ & $14.1 \%$ & $41.9 \%$ & $44.0 \%$ & $100.0 \%$ \\
\hline $30-31 / 5 / 00$ & $12.7 \%$ & $45.2 \%$ & $42.1 \%$ & $100.0 \%$ \\
\hline $24 / 5 / 99$ & $15.4 \%$ & $45.1 \%$ & $39.6 \%$ & $100.0 \%$ \\
\hline $26 / 5 / 98$ & $12.8 \%$ & $31.5 \%$ & $55.7 . \%$ & $100.0 \%$ \\
\hline $27 / 5 / 97$ & $12.9 \%$ & $53.4 \%$ & $33.8 \%$ & $100.0 \%$ \\
\hline $22-23 / 5 / 96$ & $12.3 \%$ & $48.4 \%$ & $39.3 \%$ & $100.0 \%$ \\
\hline $29-31 / 5 / 95$ & $14.3 \%$ & $49.2 \%$ & $36.5 \%$ & $100.0 \%$ \\
\hline $17-20 / 5 / 94$ & $12.2 \%$ & $49.2 \%$ & $38.5 \%$ & $100.0 \%$ \\
\hline $10-11 / 5 / 93$ & $11.5 \%$ & $54.5 \%$ & $34.0 \%$ & $100.0 \%$ \\
\hline
\end{tabular}

The importance of 4 June in the political culture is confirmed by opinion polls on the attitude of Hong Kong citizens towards the Alliance in Support of the Patriotic proDemocracy Movement in China, which has organised the vigils and activities to support Chinese democrats ever since its foundation in 1989. Although the authorities hinted that it might be dissolved after the handover on the grounds that it was "subversive," for the last ten years the inhabitants of the SAR have repeatedly affirmed their commitment to its continuing existence. Thus, in reply to the question: "Do you think that the Alliance should be disbanded?," over $40 \%$ replied in the negative (except in 1998, when it was endlessly denounced by the authorities), whereas positive replies have never risen above $20 \%$. This shows that a large majority make a connection between their condemnation of the 4 June incident and their actual ability to express it in public demonstrations. That too is an important characteristic of the political culture of the population.

For a large majority of the inhabitants, the condemnation of the suppression of the 1989 movement entails a number of consequences, including the particular role of the SAR in the democratisation of China. So in response to the question: "Do you think Hong Kong people have a responsibility to instigate the development of democracy in China?,"
Table 5. "Do you think Hong Kong people have a responsibility to instigate the development of democracy in China?"

\begin{tabular}{lcc|cc|}
\hline $\begin{array}{l}\text { Date of } \\
\text { Survey }\end{array}$ & Yes & No & $\begin{array}{c}\text { Don't } \\
\text { know } / \\
\text { Hard to } \\
\text { say }\end{array}$ & Total \\
\hline $18-25 / 5 / 06$ & $76.2 \%$ & $16.9 \%$ & $6.9 \%$ & $100.0 \%$ \\
\hline $21-24 / 5 / 05$ & $75.4 \%$ & $12.9 \%$ & $11.7 \%$ & $100.0 \%$ \\
\hline $18-20 / 5 / 04$ & $70.7 \%$ & $15.9 \%$ & $13.4 \%$ & $100.0 \%$ \\
\hline $15-20 / 5 / 03$ & $69.9 \%$ & $16.0 \%$ & $14.1 \%$ & $100.0 \%$ \\
\hline $14-16 / 5 / 02$ & $68.1 \%$ & $15.2 \%$ & $16.7 \%$ & $100.0 \%$ \\
\hline $25-29 / 5 / 01$ & $72.4 \%$ & $15.1 \%$ & $12.6 \%$ & $100.0 \%$ \\
\hline $30-31 / 5 / 00$ & $71.8 \%$ & $12.9 \%$ & $15.3 \%$ & $100.0 \%$ \\
\hline $24 / 5 / 99$ & $76.9 \%$ & $11.4 \%$ & $11.7 \%$ & $100.0 \%$ \\
\hline $26 / 5 / 98$ & $73.8 \%$ & $11.4 \%$ & $14.8 \%$ & $100.0 \%$ \\
\hline $27 / 5 / 97$ & $75.2 \%$ & $13.4 \%$ & $11.4 \%$ & $100.0 \%$ \\
\hline $22-23 / 5 / 96$ & $77.8 \%$ & $10.4 \%$ & $11.8 \%$ & $100.0 \%$ \\
\hline $29-31 / 5 / 95$ & $79.9 \%$ & $7.3 \%$ & $12.8 \%$ & $100.0 \%$ \\
\hline $17-20 / 5 / 94$ & $79.3 \%$ & $8.4 \%$ & $12.4 \%$ & $100.0 \%$ \\
\hline $10-11 / 5 / 93$ & $83.6 \%$ & $6.1 \%$ & $10.3 \%$ & $100.0 \%$ \\
\hline
\end{tabular}

about $76 \%$ replied in the affirmative. This shows that SAR residents are well aware that their political culture is more advanced than that on the mainland, and that they believe it should be extended to cover the whole of China.

These polls show that Ma Lik is quite right to consider attitudes towards the Tiananmen massacre to be a major element in the political culture of the SAR which, if it remains unchanged, will remain very different from that on the mainland (which he calls the "national identity," as though Chinese national identity includes a refusal to acknowledge that a massacre occurred in Beijing in 1989!)

\section{The importance of demonstrations}

The freedom to demonstrate was among the 16 criteria selected by Chris Patten to judge the effective reality of the "one country, two systems" formula ${ }^{(6)}$. And, from the 1980s onwards, the number of demonstrations increased throughout the Territory, becoming a defining characteristic of its

6. Jean-Philippe Béja, "Un an de politique à Hong Kong: Une divine surprise?", Perspectives chinoises, $n^{\circ}$ 47, May-June 1998, p. 6, and "Policy Address", SCMP, 3 October 1996 
"Hong Kong will not be ready for universal suffrage until 2022 because its people lack a sense of national identity", Ma Lik political culture. This too is a distinctive feature which marks the SAR off from the mainland. On the other side of the Shenzhen River, the right to demonstrate does not exist, although it is guaranteed by the Constitution.

Since 1 July 1997, there have been about 1,000 demonstrations per year, or about three a day (see tables 6, 7 and 8). So, contrary to the fears expressed after the provisional Legco amended the Public Security Act to restrict the right to demonstrate (by introducing the need to seek authorisation for marches and by reducing the numbers allowed to congregate without authorisation from 30 to $20^{(7)}$ ), the number of demonstrations did not fall but became a regular feature of the SAR. On the whole, Hong Kong people believe that they enjoy considerable freedom in this respect. But they also think the situation could be better since, when asked to evaluate it on a scale of $0-10$, they put it within a range of 6.19 at its lowest (in the first quarter of 1998) to 7.71 at its highest (in the first quarter of 1996), while it currently stands at $7.48^{(8)}$.

The reasons for the demonstrations range widely from wage demands to heritage preservation, trade union rights, universal suffrage etc. But the important point is that demonstrating is considered by all inhabitants, whatever their political position, to be a natural and legitimate form for expressing opinions. There are two types of demonstration; the first involving gatherings of several dozen or even hundreds of people, usually in front of a government building, aimed at defending sectional interests or protesting against certain measures taken by the state. These are by far the most numerous, and their political character is by no means clear. But they represent a specific characteristic of Hong Kong's political culture, and can probably be explained by the large number of associations which make up its extremely lively civil society ${ }^{(9)}$, as well as by the ease in meeting the formal requirements to be allowed to demonstrate.

The other type of demonstration is more spectacular, and it indicates the level of politicisation of the population. This type consists of a march by tens or even hundreds of thousands of people when they feel their way of life is under threat. In such cases, neither the SAR government's urging of restraint, nor the warnings from the central government, manage to contain the flood. The clearest example was doubtlessly the demonstration on 1 July 2003 which attracted over 500,000 people, surprising not only the police but also the organisers who had expected only 100,000. The issue was the introduction of legislation aimed at enacting anti-subversion measures. This was viewed as an attempt to restrict existing freedoms, and therefore calling into question the basis of the system established in Hong Kong for sev-

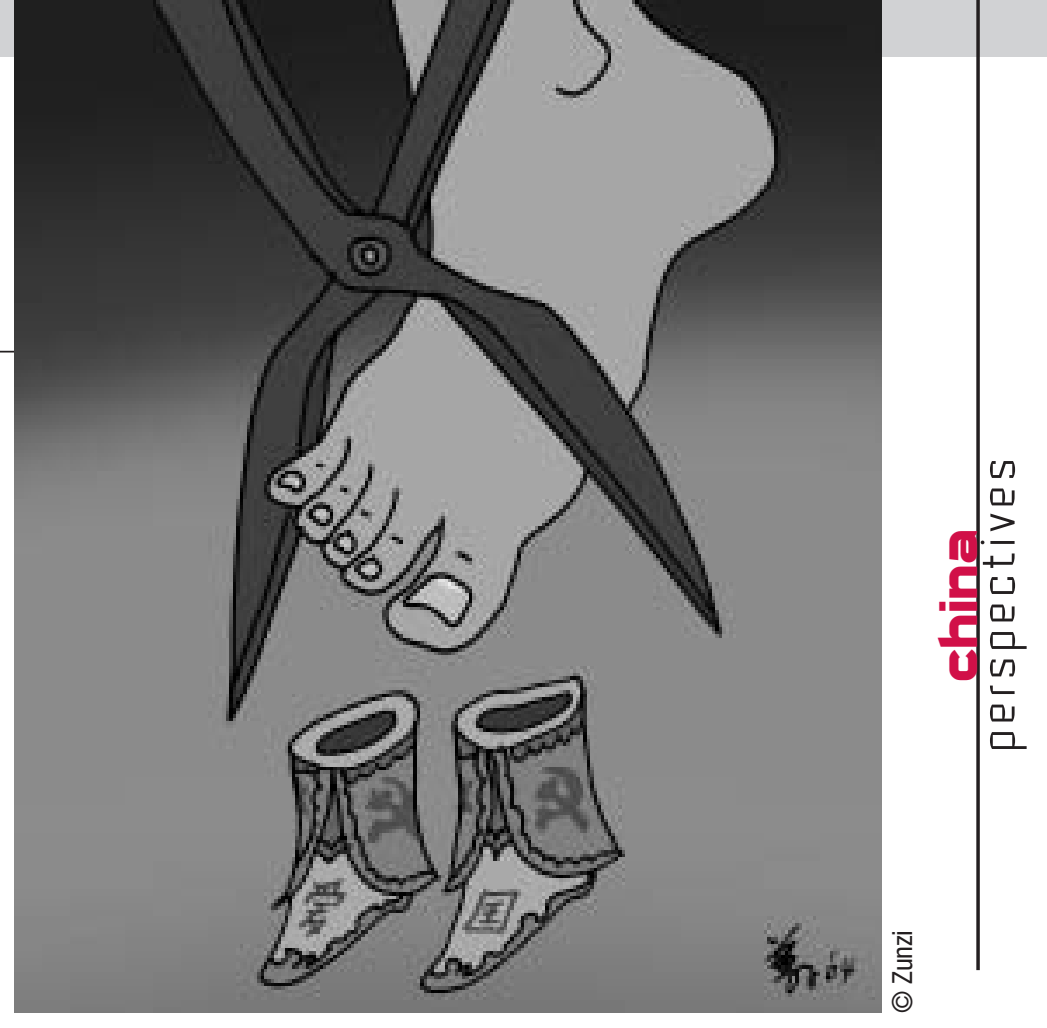

eral decades. The success of this march was all the more surprising as it was organised by a group of lawyers who had only recently turned to politics, around their Civil Human Rights Front. That did not prevent the demonstration from taking place in an atmosphere of impressive calm, which shows that the population knows how to behave on such occasions. And just as in 1989, the police did not intervene, showing that their attitude had not changed over the years since 1997.

Other large-scale demonstrations took place on 1 January $(100,000)$ and 1 July $2004(300,000)$ to demand that the chairmen of the Executive and Legislative Councils be elected by universal suffrage and to protest against the refusal by the National People's Congress to agree to these demands. On these occasions too, although the pro-democracy parties took part, it should be noted that the associations from civil society grouped around the Civil Human Rights Front played an essential role in organising the marches. The breadth of these demonstrations is all the more striking since the demonstrators on 1 July knew perfectly well that their actions would annoy Beijing ${ }^{(10)}$, not just the local government which was taking the side of the central authorities. But that did not prevent them from participating en masse. Their response made it clear that Tung Chee-hwa's and the Beijing authorities' statements, to the effect that Hong is a city whose inhabitants are essentially concerned with the state of the economy, do not correspond to the reality. Whenever the way of life and the system of freedoms gov-

7. Linda Choy, Colin Ley, "Talking Liberties", SCMP, 21 May 2007

8. Opinion poll with the instruction: "Please use 0-10 to evaluate the extent of freedom of procession and demonstration in Hong Kong", HKU pop.site, http://hkupop.hku.hk/

9. See the article by Christine Loh in this issue

10. A poll conducted among 732 participants in this demonstration revealed that 547 said that they wished to show their dissatisfaction with recent positions adopted by Beijing "Qi.yi 2004 wanshang diaocha yijian tongji" (statistics from the internet survey on the 1 July 2004 demonstration), http://hkupop.hku.hk/http://hkupop.hku.hk/ 
Tables 6, 7 and 8

\section{What is the extent of freedom of speech in HK?}

Half-yearly polls, responses from 0 (no freedom) to 10 (complete freedom)

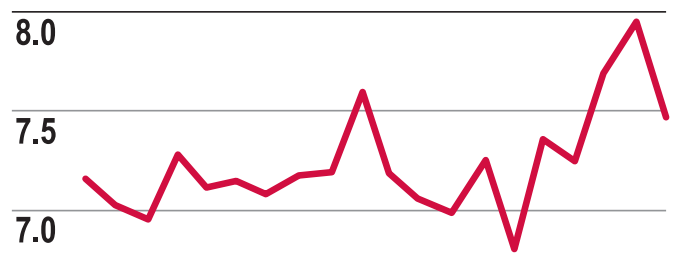

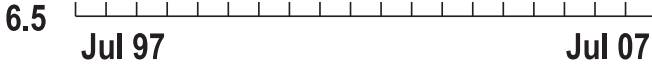

What is the extent of freedom of procession and demonstration in HK?

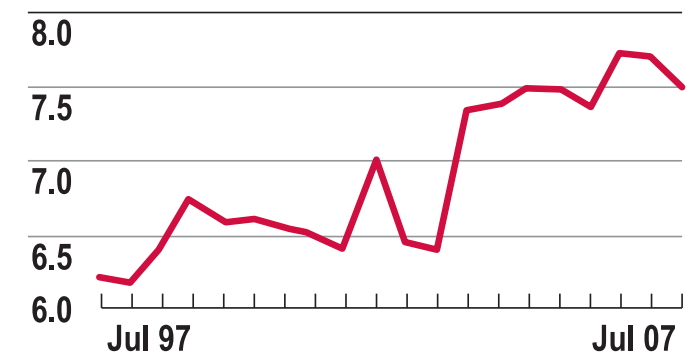

\section{Number of protest rallies and gatherings}

Public processions $\quad$ Public meetings

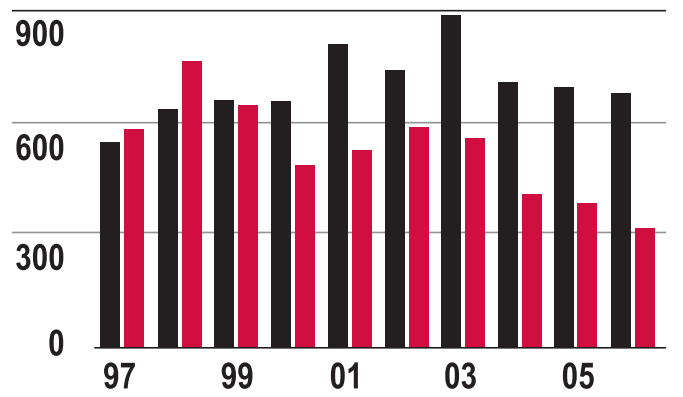

Source: HKU Public Opinion Programme, HK Police.

erning Hong Kong are threatened, the inhabitants do not hesitate to take to the streets. This justifies our view that large demonstrations with political objectives constitute an important aspect of the political culture of Hong Kong.

We might even risk the hypothesis that it is precisely because there is no election by universal suffrage to the whole of the Legislative Council and to the post of Chief Executive that the demonstrations are so numerous. Given the constraints imposed by the Basic Law, only those social forces favourable to Beijing and to business circles can exercise any power. That is why the democrats, who have won about $60 \%$ of the votes in each of the elections by direct suffrage which have been held since the handover, can never take part in the government. Under these circumstances, dissenting opinions can never carry the day in governing bodies, so they find an outlet in the streets, putting pressure on those in power who are thus obliged to take it into account. In this regard, it must be acknowledged that demonstrations quite often manage to influence the decisions of the government. The case of the demonstration on 1 July 2003 is a good example of this. At the end of July, James Tien, the leader of the Liberal Party and a member of the Executive Council, resigned in protest against Tung Chee-hwa's refusal to withdraw the proposal to incorporate Article 23 into the legislation ${ }^{(I I)}$. By 5 September, however, Tung eventually withdrew it, saying "I think that we need to re-examine the whole issue." He told reporters at a hastily scheduled news conference in Hong Kong, "We will want to consult very widely in the community again, and until there is sufficient consultation and support, we are not going ahead [with the bill] ${ }^{(12) . " ~ B y ~ t a k i n g ~ t h i s ~ s t e p, ~ t h e ~ C h i e f ~ E x e c u t i v e ~ w a s ~ r e c o g-~}$ nising the legitimacy of the demonstration. The success of the march on 1 July 2004 against Beijing's refusal to introduce universal suffrage also had important consequences. In February 2005, the central government allowed Tung Cheehwa to retire "for health reasons," thereby acknowledging that he no longer possessed sufficient legitimacy to remain in his post. He was replaced by Donald Tsang, who was at the time government Secretary and a leading member of the former colonial administration, and who enjoyed far greater popular support. So the experiences of the last decade show that demonstrations are effective means for the citizens to exert influence over the political development of the SAR. They are currently a major element in its political culture.

\section{The commitment to democracy and electoral participation}

Although the citizens of Hong Kong take every opportunity to call for the introduction of complete democracy, they at-

11. James Tien in Letter to Hong Kong, RTHK Radio 3, 27 July 2003.

12. Philip Pan, "Hong Kong Chief Drops Unpopular Security Bill", Washington Post, 6 September 2003 
tach great importance to participation in the current political institutions. This is another important aspect of the SAR's political culture. Regular public opinion polls have shown that Hong Kong people are not satisfied with the level of democracy in the SAR, and believe this has worsened since the handover. On the eve of the fateful date in June 1997, the level of positive assessment on a scale from 0 to 10 was 6.7. Since then it has never been that high. The highest point over the last decade was 6.45 in March 1999 (6.08 in February 2007), and the lowest was 5.59 in July $2003^{(13)}$. In spite of this poor result (or perhaps because of it), Hong Kong people show great interest in political campaigns and debates. For example, in March 2007 the two debates between Alan Leong, a member of the Civic Party, and the incumbent Donald Tsang for election to the post of Chief Executive, were both followed by a television audience of two million, out of a total population of seven million ${ }^{(14)}$. Even though there could be no doubt about the outcome, since Alan Leong could get no more than 132 votes out of the 800 on the electoral commission, it gave the democrats the opportunity to question the Chief Executive and to oblige him to defend his record and his future plans. He was brought down from his pedestal and made to justify himself before his fellow citizens, even if the latter were not his electors. That was certainly a step forward in Hong Kong politics, and the re-elected Chief Executive recognised as much, writing in his blog after the debate, "There is no question of who wins or who loses. The result is that we [Mr. Leong and I] have contributed in different ways to Hong Kong's political development ${ }^{(15)}$." And in fact it is highly likely that, whatever Beijing may wish, the next election to the post of Chief Executive will have to be contested, and to include a debate between the candidates. The interest taken by the population in these televised debates shows that the SAR's political culture is in many ways similar to that of Western democracies.

There is another similarity too, namely the numbers participating in the elections, although these are a relatively recent phenomenon since the first elections with universal suffrage only taking place in 1991. These too have become an integral part of the culture. In the decade since the handover, the numbers taking part have developed unevenly, from a record $53.29 \%$ in $1998^{(16)}$ down to $43.6 \%$ in $2000^{(17)}$, and up to a new peak of $55.6 \%$ in $2004^{(18)}$. It is worth noting that participation increases with political tensions. In 1998, just after the handover, being important to show commitment to the elections, residents turned up in large numbers at polling stations. In 2000, by contrast, there was no press- ing political problem, the people were demoralised, and voting numbers were relatively low. But in 2004, one year after the large demonstration against Article 23 and immediately after the other large demonstration against the central government's restrictions on the development of democracy ${ }^{(19)}$, voters turned up en masse. And this despite violent attacks by the Beijing authorities, relayed by their Hong Kong mouthpieces, accusing the democrats of a lack of patriotism ${ }^{(20)}$.

So voter turnout has become an increasingly entrenched feature of Hong Kong's political culture. But it has another noteworthy aspect: since the introduction of universal suffrage for the elections to Legco, the candidates from the pan-democratic camp, who favour universal suffrage and are keen to maintain the SAR's autonomy in relation to China, have always won about $60 \%$ of the votes, with a maximum of $64.7 \%$ in 1991, and a minimum of $57.16 \%$ in 2000 (and $60.63 \%$ in 2004) ${ }^{(21)}$. These figures show that this political current is supported by a large majority of the population who are concerned with the defence of the special nature of the political system, and are in favour of democratisation. The concept of direct universal suffrage (as an aspiration, at least) has become such an integral part of the political culture of the SAR that in 2004 even those parties representing business circles, which used to prefer to put forward candidates only through the professional functional constituencies, entered some in the geographical constituencies, thus showing that they too believed that legitimacy based on universal suffrage was superior to that which is conferred by small elite groups. The leaders of the Liberal Party, James Tien and Selina Chow, who had the courage to face the voters, were actually elected. Similarly, the circles who support Beijing, despite their hostility to "bourgeois democracy,"

13. "If you were to use $0-10$ to evaluate how democratic a society Hong Kong is, with 10 indicating absolutely democratic, 0 indicating absolutely autocratic, 5 indicating halfhalf, how would you rate Hong Kong?", HKU Popsite, http://hkupop.hku.hk/

14. Edward Cody, "Tsang Re-Elected as Hong Kong's Leader," Washington Post, 25 March 2007.

15. Quoted in Denise Hung, "Tsang's change of tactics puts Leong on the spot in TV election debate," SCMP, 16 March 2007.

16. See Jean-Philippe Béja, art. cit., May-June 1998.

17. Chris Yeung, "Slicing up the Political Pie," SCMP, 12 September 2000

18. J-Ph. Béja and F. Cini, "Hong Kong en liberté surveillée," Politique internationale, $\mathrm{n}^{0} 106$, Winter 2004-2005, p. 343.

19. Christine Loh, "Hong Kong's Relations with China: the Future of 'One Country, Two Systems'," Social Research, vol. 73, n 1, Spring 2006, p. 301.

20. China Daily, Hong Kong edition, 5 March 2004.

21. Ma Ngok, "La démocracie dans l'impasse à Hong Kong," Perspectives chinoises, n 86 , November-December 2004, p. 50. 
have founded a party which regularly puts up candidates in the geographical constituencies. In the recent elections they won nine out of the thirty available seats ${ }^{(22)}$, becoming the leading party in the SAR. Even though these representatives of conservative or pro-Beijing groups continue to claim that the population is not mature enough to elect its leaders through direct universal suffrage, they concede legitimacy to that mode of leadership selection which has now become an essential element of Hong Kong's political culture.

The need to put forward candidates for the elections has induced the forces on the ground in the SAR to organise into parties, but these lack maturity and are not deeply embedded in the political life of the territory. Even the oldest (the HKUD?Hong Kong Union of Democrats) only goes back to 1991, and in 1992 the pro-China forces set up the Alliance for the Betterment of Hong Kong. This is the party with the largest membership $(9,919$ according to official figures) ${ }^{(23)}$, while the democrats only have $631^{(24)}$. The pandemocratic camp has not managed to found a unified organisation, and is still divided into three parties.

However, despite their extremely short history and their inexperience, the parties play a considerable role in the political culture of the SAR. Even if their membership is low, opinion polls show that the population believes that they are important, since they enjoy a level of support varying from $48 \%$ to $51 \%{ }^{(25)}$. Above all they are known to the public. $89 \%$ of those interviewed knew about the democrats, $85.1 \%$ about the DAB, and $71.5 \%$ about the Civic Party ${ }^{(26)}$, although the latter had only existed for two years when the poll was conducted. In this respect too, the political culture of Hong Kong is clearly close to that of other democracies. This article has been concerned with identifying the specific features of Kong Kong's political culture. These have been sustained and strengthened throughout the decade since the return of the Territory to the motherland. Ten years of integration into the PRC have not brought about any deep changes. On the contrary, the features of Hong Kong's political culture have grown stronger. This can be explained by the fact that on the whole the "one country, two systems" formula has worked relatively well. The Chinese Communist Party has not taken over the SAR, the political and legal systems remain very different from their mainland counterparts, and Hong Kong enjoys the basic freedoms underwritten by its independent judiciary. However, the fact that Beijing plays a major role in decisions concerning the SAR's development has led to the strengthening of certain specific features of its political culture. Since the central government has constantly opposed the introduction of universal suffrage for elections to leading political positions, the inhabitants of the SAR have resorted to a large number of demonstrations in support of their claims. On every occasion, these have been provoked by the decisions taken by the central government, and they have been directed against the government of Hong Kong. Demonstrations therefore currently constitute a major (and perhaps abnormal?) element in the SAR's political culture. Similarly, the vigils held every 4 June to commemorate the repression of democracy in China, are also a reaffirmation of the specific nature of that culture.

In conclusion, as Joseph Man Chan and Francis Lee have written: "Hong Kong people regard themselves as belonging to a Chinese cultural community, but they are more reluctant to regard themselves as belonging to a political community headed by the Chinese government ${ }^{(27)}$." •

\section{- Translated by Jonathan Hall}

22. http://www.dab.org.hk/en/main.jsp?content=category-contentjsp\&categoryld=1055 accessed on 22 May 2007.

23. http://www.dab.org.hk/en/main.jsp?content=category-content.jsp\&categoryld=1019

24. http://www.dphk.org/2003/basicinfo/index.asp?iCommentlD=146

25. "Rating of Top Ten Political Groups," http://hkupop.hku.hk/

26. Ibid.

27. Francis L. F. Lee and Joseph Man Chan, "Political Attitudes, Political Participation, and Hong Kong Identities after 1997," Issues and Studies, vol. 41, n², p. 15. 